Омельковець, Руслана і Христіанінова, Раїса. «Флористичні найменування в поетичній збірці Віктора Лазарука „Літораль”: функціонально-стилістичний аспект». Лінгвостилістичні студї, вип. 14, 2021, c. $100-12$.

Omelkovets, Ruslana, and Khrystianinova, Raisa. "Floristic Names in V. Lazaruk's Collection of Poetry "Litoral": Functional and Stylistic Aspects". Linguostylistic Studies, iss. 14, 2021, pp. 100-12.

УДК 811.161.2'373.2:581.9]+821.161.2(477.82)'06.08Лазарук

https://doi.org/10.29038/2413-0923-2021-14-100-112

\title{
ФЛОРИСТИЧНІ НАЙМЕНУВАННЯ В ПОЕТИЧНІЙ ЗБІРЦІ ВІКТОРА ЛАЗАРУКА «ЛІТОРАЛЬ»: ФУНКЦІОНАЛЬНО-СТИЛІСТИЧНИЙ АСПЕКТ
}

\author{
Руслана Омельковець \\ Волинський національний університет імені Лесі Українки, \\ Луцьк, Україна \\ Раїса Христіанінова \\ Запорізький національний університет, \\ Запоріжжя, Україна
}

У статті наведено набір фітономенів у художньо-поетичному мовленні В. Лазарука на прикладі поезій збірки «Літораль», здійснено аналіз семантико-стилістичного потенціалу цих лексем, з'ясовано функціонально-стилістичні особливості флоронайменувань як одиниць поетичного мовлення. Фактичний матеріал засвідчує продуктивність використання флоролексем у ролі стилістем та ексресем широкого емоційно-оцінного плану. Образна природа флоролексем підпорядковується індивідуально-авторському осмисленню.

Ключові слова: лексема, флорономени, символ, персоніфікація, метафора.

\section{FLORISTIC NAMES IN V. LAZARUK'S COLLECTION OF POETRY “LITORAL”: FUNCTIONAL AND STYLISTIC ASPECTS}

\author{
Ruslana Omelkovets \\ Lesya Ukrainka Volyn National University, Lutsk, Ukraine \\ Raisa Khrystianinova \\ Zaporizhzhia National University, Zaporizhzhia, Ukraine
}

The article elucidates the issue of phytonomes revealed in the poetic collection "Litoral" by Victor Lazaruk and analyzes the semantic and stylistic potential of these lexemes with an emphasis on the functional and stylistic features of floral names in terms of the poetic speech units.

The phytonomes that occur in the poetic collection of Victor Lazaruk's "Litoral" form a rich in repertoire thematic group of vocabulary. The degree of signifiers' representation in it is various. Fixed in the collection florolexemes are divided into several lexical and semantic subgroups: dendro-lexemes (trees, shrubs/bushes), names of herbaceous plants, and crops.

(C) Омельковець Р., Христіанінова Р., Волинський національний університет імені Лесі Українки, 2021.

Це стаття відкритого доступу на умовах CC BY-NC 4.0 
The total number of the recorded units is 83 (33 names of woody plants, 44 names of herbaceous plants, 6 names of crops).

The functional activity of the lexical-semantic group of florolexemes can be illustrated by the following quantitative indicators: total - 242 word usage; dendro-lexemes - 142 word usage; names of herbaceous plants - 88 word usage; crops - 12 word usage. Dendro-lexemes birch (29 fixations) and oak (20 fixations) demonstrate the highest frequency level.

The case study material testifies to the productivity of flora-lexemes in the function of style-semes and expressemes with a wide emotional and evaluative potential. The figurative meaning of phyto-names is always a matter of the author's individual comprehension.

The study has revealed that most of these floral names are distinguished by positiveemotional and minor coloration. In numerous landscape descriptions, flora-lexemes are organically woven into the linguistic and poetic structure of the text. They create a distinct local-national coloring of the image, characterize the seasonal changes of nature, symbolize the attributes of space, embody the unity of generations, glorifying the glorious past and giving faith in a bright future.

Key words: lexeme, floronomens, symbol, personification, metaphor.

Вступ. На початку XXI століття зросла зацікавленість дослідників проблемами реалізації в художньому мовленні семантико-стилістичного потенціалу слів різних тематичних груп. Значний шар лексикосемантичної системи української мови складає флористична лексика, тому цікавим $\epsilon$ вивчення фітономенів як засобу увиразнення прозових i поетичних текстів. Незважаючи на підвищений інтерес науковців до цієї проблеми, питання стилетворчого потенціалу фонду мовновиражальних засобів флоролексикону залишилося недостатньо розкритим, оскільки було предметом опису лише окремих мовознавчих студій. Так, флоронайменування у цьому напрямі досліджували Л. В. Голоюх, Н. О. Данилюк, Г. А. Єщенко, В. С. Калашник, М. В. Кудряшова, І. Є. Подолян, Л. О. Савченко, О. І. Сімович, Л. О. Ставицька, І. В. Шапошникова, Л. В. Оліференко, О.Ю.Дубовик, Л. Е.Петрухіна, В. В.Галайчук та ін.), але поглиблено це питання представлено лише в дисертації I. I. Коломієць.

Флористичні найменування належать до найдавніших шарів лексики. Вивчення їх як засобів емоційно-експресивного впливу зумовлене глибокою традиційністю використань рослинних номінацій у текстах різних стилів і жанрів (Коломієць 3).

Отже, потреба детального розгляду закономірностей мовноестетичного перетворення флористичних одиниць та висвітлення різноманітних стилістичних ефектів їх використання зумовлює актуальність нашого дослідження.

Мета роботи полягає в аналізі семантико-стилістичного потенціалу флоролексем у поетичній збірці Віктора Лазарука «Літораль». Досягнення поставленої мети передбачає виконання таких завдань: визначити набір флорономенів у художньо-поетичному мовленні В. Лазарука на прикладі поезій збірки «Літораль»; з'ясувати функціонально-стилістичні особливості флоролексем як одиниць поетичного мовлення. 
Матеріал і методи дослідження. Поставлена мета визначає використання таких методів лінгвістичного аналізу: описового (виявлення флоролексем та їхню систематизацію), контекстного (визначення специфіки поетичних уживань), компонентного (сприяє визначенню структурних елементів флористичних слів-образів для з'ясування їхнього стилістичного призначення в системі мовновиражальних засобів твору).

Результати дослідження та дискусія. Дерева й кущі, квіти і трави завжди були невід'ємною частиною життя українців, тому флорономенам належить важливе місце серед лексичних засобів вираження авторського естетичного погляду на довкілля. Твори письменників на волинську тематику, які часто стають зразком живої народної мови, фіксують значну кількість фітономенів і термінів травництва, що допомагає яскраво відтворити самобутність поліського краю (Омельковець 112).

Значна кількість флоролексем трапляється і в поезіях В. Лазарука, зокрема у збірці «Літораль». Виявлені тут флорономени можна поділити за такими лексико-семантичними групами (далі ЛСГ): дендролексеми (дерева, кущі), назви трав'янистих рослин та сільськогосподарських культур. Всього зафіксовано 83 одиниці (33 назви дерев'янистих рослин, 44 назви трав'янистих рослин, 6 назв сільськогосподарських культур).

Функціональна активність ЛСГ характеризується такими кількісними показниками: всього - 242 слововживання; дендролексеми - 142 слововживання, зокрема береза (берез) - 29 фіксацій, дуб - 20 фіксацій, явір 8 фіксацій, осика, сосна, калина, яблуня - по 7 фіксацій, лексема дерева 6 фіксацій, ялина, ялинник, ялівець - по 5 фіксацій, граб - 4 фіксації, верба, липа, ліщина - по 3 фіксації, лоза, вільха, каштан, горобина, кипарис - по 2 фіксації, тополя, осокір, груша, ліщина, акація, гінкго, ломонос (клематіс), юка, тамариск, терен, морський виноград, черешня, мигдаль - по 1 фіксації; назви трав'янистих рослин - 88 слововживань, зокрема лексема трава 8 фіксацій, квіт (квіти) - 6 фіксацій, цвіт - 5 фіксацій, мох - 8 фіксацій, брусниця, верес - по 5 фіксацій, багно, ведмедина - по 3 фіксації, лексема ягода - 3 фіксації, барвінок, ромашка, очерет, лілія, кульбаба, спориш, шипероха (папороть), ситняг - по 2 фіксації, лопух, гладіолус, чорнобривці, рута-м'ята, ковила, любисток, хризантема, перекотиполе, орляк (птерис), лепеха, мати-й-мачуха, меч-трава, реп'ях, заячий овес (вівсюнець пухнастий), дзвоники, братики, очеретиця (водяний манник, болотний манник), папороть, рогоза, ромашка, журавлина, полуниця, чорниця, комиш, подорожник, водорості - по 1 фіксації; назви сільськогосподарських культур - 12 слововживань, зокрема горох - 4 фіксації, жито - 3 фіксації, капуста - 2 фіксації, цибуля, диня, льон - по 1 фіксації. Максимально високою частотністю позначені такі дендролексеми, як береза 29 фіксацій та дуб - 20 фіксацій.

Таку кількість флорономенів у поезіях можна пояснити лише величезною любов'ю Віктора Лазарука до рідного волинського краю, його 
природи, тісно переплетеною зі споконвічними таємницями. Адже, як справедливо наголошує І. В. Кузьміна, кожен «письменник починається від тієї землі, на якій побачив світ. Ї̈̈ мальовнича краса, її дихання, її тремкий, ледь уловимий запах проникають у дитячу душу і залишаються в ній назавжди» (Кузьміна). Через відгомін прадавніх вірувань, завдяки відкритим порталам у минулі століття історії Волині, поет формує систему глибоких та нетривіальних символів. Відтак підхід до актуальних, тісно пов'язаних між собою проблем екології та людської ментальності відбувається через старовинні повір'я, легенди та прикмети. Олюднення флори та фауни волинського пралісу дає змогу їі представникам промовляти $з$ поезій Віктора Лазарука до людей не просто на правах «менших братів». Суть таких віршів полягає не в повторенні типових закликів берегти природу, а саме в розкритті її зв'язку з генетичною пам'яттю нашого народу. Сакралізація природи не $\epsilon$ перебільшенням, а способом підкреслити велич її первозданної краси. Водночас надприродне у віршах Віктора Лазарука часто межує з буденністю, казка іронічно відтіняє реальність. Варто зауважити, що краєвиди Ковельщини, оспівані поетом, змалку надихали ще авторку «Лісової пісні». Леся Українка так само була закохана в таїну мавчиного лісу, майстерно актуалізуючи тему людини й природи, споконвічного й минущого, тому не буде перебільшенням очевидна спадкоємність цієї феєричної традиції, яка отримала «друге дихання» в поезіях Віктора Лазарука.

У вірші «Замчисько» Віктор Лазарук уміло поєднує за допомогою метафор історію рідного краю з його флорою (20). «Юний цвіт» сьогодення росте на тлі «сивих мурів», вочевидь, замків волинської землі. Фігурують тут і рослини 3 конкретними назвами. Так, півень в гущавині лопухів (Arctium L.) набуває образу середньовічного монарха, що тамує спрагу після битви. Не дивно, адже округле та серцевидне листя нагадує наплечники лицарського обладунку саме такої форми. Велика кількість трави під стінами замку викликає в автора асоціацію з ординцями, що ведуть облогу, а саме з їхніми списами. Однобічне суцвіття червоного гладіолуса (Gladiolus primulinus) на міцному високому стеблі постає в образі закривавленої алебарди - короткоклинкового давньоримського меча-гладіуса, адже листя цієї рослини нагадує лезо. Ще одна назва Gladiolus primulinus - косарики (Олєйнікова 48). Тут узято до уваги ще й довге стебло, яке у поєднанні з квітами довершує вигляд коси. Отже, автор недаремно помітив схожість гладіолуса саме до держакової зброї, популярної серед пізньосередньовічного литовсько-руського лицарства. Осінь у «цибулиних кайданах», ймовірно, мусить нагадати читачеві гирі, причеплені до ніг в'язня. Каштану (Castanea Tourn) поет надає вигляду шляхтича в кунтуші, можливо, за пишну форму крони, а, відповідно до пори року, про яку йдеться у вірші, - ще й за золотаво-червоний колір листя. Ці барви верхнього одягу були популярні серед родової аристократії Великого князівства Литовського, Речі Посполитої та Гетьманщини. 
Жовтий жупан часто поєднувався 3 кармазиновим кунтушем (тандем кольорів могли використовувати й навпаки). Верби (Salix L.), споконвічно ототожнювані в українській усній народній творчості 3 вродливими дівчатами, розмовляють із циганом-туманом, ладним, «бабурячи», дурити голови красуням.

У вірші «Діалог в чистому полі» автор порівнює воронячу зграю 3 листям тополі чорної (Populus nigra L.) (Лазарук 10). Звуки десятків воронячих крил, що тріпочуть, недаремно асоціюють саме з тремтінням листя тополі. Древньолатинська назва рослини походить від «palpito»тріпотіти - за гру листя під час поривів вітру (Фармацевтична енциклопедія). В українському фольклорі тополя символізує смуток і самотність, супроводжуючи наймеланхолійніші пісні та балади.

Кілька разів у збірці автор згадує липу (Tilia), зокрема в поезії «Змістився в часі календар». Цвітіння цієї рослини в перший місяць літа викликає асоціації з несвоєчасністю та безладною метушнею в наш час (Лазарук 30). Природні аномалії, наведені у вірші («Січневий дощ січе із хмар, / А сніг лапатий в липні випав»), є тлом, завдяки якому автор описує мінливу й хаотичну буденність людства наприкінці XX століття.

Дупла старої липи у вірші «На хуторі» (Лазарук 42-43) постають універсальними органами слуху та зору, якими вона нібито споглядає сільський пейзаж довкола. За допомогою епітетів автор підкреслює поважний вік дерева, яке за своє життя набуло досвіду пильного очевидця.

Гордовиту дівчину в поезії «Асорті» Віктор Лазрук порівнює 3 пелюсткою мигдалевого горіха:

Зблідлою пелюсткою мигдалю

Ти мені всміхнулася в листі (Лазарук 50).

Ця популярна кондитерська прикраса являє собою тонкі сушені пластівці плодів мигдалевого дерева (Prunus dulcis), які внаслідок правильного приготування мають характерний блідий колір. Отже, вжите порівняння вказує на бліде обличчя красуні.

Вірш «Зелен явору, червоній калині (весільний тост)» (Лазарук 52) автор недаремно називає весільним тостом, адже 3 назви зрозуміло, що явір та калина - це молодята, яких поет віншує в кращих народнопісенних традиціях. Казкової урочистості надає залучення до весільного обряду, за допомогою барвистої персоніфікації, дерев та квітів як повноправних учасників дійства, яким надана почесна місія. Сяяти для молодих поет закликає суцвіття каштану (Castanea), яке за продовгасту форму та білорожевий колір в народі називають «свічкою»:

Засвітіть, каштани, міріади свіч!

Хай пройдуть закохані крізь ніч! (Лазарук 52).

Типові для українських подвір'їв та садів чорнобривці (Tagetes) та яблуні (Malus) відтворюють радісний настрій дійства. Нарешті увесь світ має простелитися молодій парі хрещатим барвінком (Vinca) - стародавнім 
елементом українського весілля, що символізував освячення шлюбу громадою:

Милі мої чорнобривці, звеселіте хату,

Яблуні, всміхніться, бо пора, Простелись барвінковохрещато,

Світе мій, одкрийся для добра! (Лазарук 52).

У вірші-тості автор пропонує підняти чарки за дорогі серцю речі. Серед них підкреслена метонімією любисткова купіль, пов'язана 3 періодом дитинства, коли до ночов малечі кладуть любисток лікарський (Levisticum officinale), щоб красивою була та люди любили. Так кажуть неспроста, адже ця рослина має відновлювальні та протизапальні властивості, а відтак оздоровлює шкіру та волосся дитини. На завершення тосту лунає життєстверджувальне: «За рід, за руту-м'яту, за народ!» Поєднання в українському фольклорі двох рослин рути й м'яти в одне ціле руту-м'яту символізує дівочу красу, чистоту та честь.

Персоніфіковані дерева постають не лише у сповненому містичної величі образі язичницьких божеств («Дуб дядька Лева» (Лазарук 126)), але й цілком пересічних людських типажів («Вітряний вечір» (Лазарук 60)). У другому випадку дерева до неохайності обшарпані, похмурі, трясуться та шепочуться, що надає образу рис представників суспільного «дна».

У поезіях, написаних під час санаторного лікування в Криму, Віктор Лазарук часто згадує флору, характерну для півдня України. Так, спілкуючись із кримською сосною, відомою як Палласова (Pinus nigra ssp. pallasiana), ліричний герой розповідає їй про свої сердечні переживання («Я спитав про тебе в кримської сосни» (Лазарук 64)).

Лаконічно, але, 3 іншого боку, чи не у всій своїй красі описана зовнішність такої екзотичної вічнозеленої рослини, як юка (Yucca) («Ноктюрн» (Лазарук 67)). Жовтувато-білий цвіт своїми китицями дещо нагадує «свічки» каштана, згадувані автором у попередньому вірші. Крім того, юка має гостре мечоподібне листя, яке вдало доповнює своєю «войовничістю» тендітні бліді квіти.

Дерево, на честь якого автор назвав свій кримський цикл (а пізніше цілу збірку), милує око не лише стрункою красою, але й захоплює цікавою історією («Стрінемось на місячній поляні» (Лазарук 68)). Кипариси (Cupressus) вперше з'явилися в Криму ще в античні часи, проте місцеві легенди пов'язують їх походження 3 дівчиною, що не дочекалась із плавання коханого та завмерла на березі в подобі дерева. Існує й легенда про покарання богами невдячних та лихих доньок місцевого рибалки, яких було перетворено на дерева. Наймолодшій доньці - Кипарисі - за надто жваву та глузливу вдачу судилося стати цим струнким та сумним представником роду хвойних.

Тамариск, що ридає, він же тамарикс (Tamarix L.), - невелике дерево, сльози якого згадує автор у поемі «Сон біля моря» (Лазарук 71), справді здатне «плакати». Влітку його кора вкривається солодкавим соком, який 
виділяють комахи-щитівки (Diaspididae), що живуть на стовбурі. Цікавою $є$ українська назва цього дерева - жидівник (жидовник, жидовинник), що також безпосередньо пов'язана з цими «сльозами», які у висохлому стані схожі на білу крупу. $€$ небезпідставне припущення, що саме від підхоплених вітром сухих крупинок тамариксового соку походить біблійна легенда про небесну манну. На Синайському півострові досі збирають її 3 дикорослих тамариксів, називаючи «небесним даром». Отже, бачимо, що згадана персоніфікація має в основі реальні спостереження за рослиною.

У цій же поемі згадано і більш знайому для українців рослину, назва якої перекотиполе. Клубки цих висохлих трав'янистих рослин вітер перекочує степами. Перекотиполе символізує непостійність, безпритульність та запустіння - явища типові для «віку відчуження», про що говорить автор.

У кримському циклі автор згадує й таку екзотичну рослину, як гінкго (Ginkgo), листя якої восени має яскравий золотий колір:

І гінкго золотий пришле від синіх таврів

Священного листа -

На щастя і добро (Лазарук 75).

Листоподібна хвоя гінкго дволопатевого (білоба) має унікальний хімічний склад та поєднує в собі величезний набір корисних властивостей. У японців це дерево $є$ втіленням життєдайних сил землі, символом любові, гармонії та довголіття. Із застосуванням персоніфікації дерево постає адресантом пам'ятного сувеніру-талісману з теплого краю.

Варто зауважити, що персоніфікація флори та фауни в творах Віктора Лазарука $\epsilon$ одним із найпоширеніших та найвишуканіших художніх засобів. Зростання молодої трави нагадує поетові прорізування молочних зубів у дитини, шелест першого весняного листя асоціюється з лепетом немовляти, пелюстки квітневого цвіту є його пелюшками:

і прорізуються молочні зуби в трави,

і лепече немовлям листя,

і пручається в пелюшках пелюсток під серцем цвіт,

і вчаться ходити молоді комети й дерева... («Волошкові досвітки. Рівнодення» (Лазарук 76)).

Хвойні ліси (бори), де найчастіше росте верес (Calluna vulgaris (L.) Hill.), за допомогою персоніфікації в дусі української фольклорної традиції постають у вірші «Золоті надвечірки. Рівнодення» (Лазарук 80) весільними боярами, одягненими в старовинні суконні плащі-киреї, на яких золотим гаптуванням $\epsilon$ шершні. Верес - рослина-медонос, тому зрозуміло, чому ці комахи зображені як прикраса вбрання волинських борів:

...красні бори, як весільні бояри,

у квітучих вересових киреях,

прошитих золотими шершнями,

на обрії стоять,

раду радять... (Лазарук 80) 
Верес, без якого важко уявити ліси Волині та Полісся, поет згадує і в інших віршах, зокрема «Ворожу на вужах, по пташиному лету...» (Лазарук 86):

Напущу туману. Геть іди, туманище!

Зарошу вереси без дощу! (Лазарук 86)

Квітучості поліським болотам додає багно (Ledum palustre L.; або Rhododendron tomentosum), згадане у вірші «Старе Полісся» (Лазарук 97). Це рослина, яка любить кислі поліські грунти й рясно розцвітає на початку літа. Йдеться тут і про солодкий аромат тростинового аїру (Acorus calamus), відомого в народі як лепеха. Саме цією рослиною на Волині встеляють долівки на Трійцю. Багно ж використовують у народній медицині. У селах його сушать у підвішених, нещільно зв'язаних пучках, проте не в житлових приміщеннях та не на сонці. Відтак місце «під стропом», себто під балкою на горищі - ідеальне для сушіння багна.

Персоніфікована метафора «плаче береза» («Березовий сік» (Лазарук 87)) має реальне підгрунтя, відоме за своєю суттю кожному чи не 3 дитинства. Хоча варто зауважити, що дерево плаче не лише тоді, коли навесні відбувається витікання соку через місця пошкодження кори, але й через виділення пазушних бруньок, що мають сильну протимікробну дію та захищають дерево від личинок шкідливих комах.

Означення «вужі-лози» («Гончий брід» (Лазарук 88)) стосується найпомітнішої зовнішньої ознаки рослини: лоза формою нагадує вужа, який у ролі сакрального хранителя пралісів трапляється у багатьох віршах Віктора Лазарука.

У вірші «Калина у явора...» (Лазарук 89) подано чи не найбільший перелік представників флори волинських лісів, які, постаючи олюдненими, спілкуються між собою, живуть своїм життям. Кожен із них тут має свій характер: усміхнений кущ ліщини викликає асоціації з життєрадісністю та оптимізмом, мовчазні дуби в жовтих осінніх кожухах - зі старечою мудрістю, тендітний пролісок мужньо бореться за життя «в амбразурі зими», що навіює читачеві образ непохитного юного бійця. Немов парубок дівчину, обіймає березу вітер, у відповідь на посмішку ліщинового куща цвіте багно.

Калину згадує Віктор Лазарук і в поезії «Лист поліської калини до Івана Драча» (Лазарук 93). Лист поліської калини, адресований відомому письменнику-шістдесятнику, нагадує українську народну казку, у якій калинова сопілка промовляє людським голосом.

Метафора «сосновий тугий сагайдак» («У сідлі кочової гори...» (Лазарук 99)) означає, ймовірно, сосновий ліс, адже стрункі сосни нагадують стріли. Ягодин (ягідник) - місце, де ростуть ягоди, тому згаданий у вірші ведмідь неспроста «заблукав» сюди поласувати.

Підбіл звичайний (Tussilago farfara L), що його в народі називають «мати-й-мачуха», справді росте при стежках, а «холодок», про який ідеться в поезії, характерний для його верхнього листя, котре з'являється після 
відцвітання квітів. Нижні молоді листки здаються теплими. Отже, за однією з відомих версій, назву рослина отримала через поєднання одразу двох «темпераментів». Відтак бачимо, що персоніфікація закладена народом у саму назву рослини, а поет створює специфічну метафору: матий-мачуха прикладає компрес, що тонізує, до скроні також живої стежки, якій млосно у спекотний літній день.

Такі ж яскраві персоніфікації трапляються і в наступних рядках («У сідлі кочової гори...» (Лазарук 99)). Занесена до Червоної книги України меч-трава болотна (Cladium mariscus), що росте у заплавах річок, постає у вірші мечником-оборонцем, у якого струмок просить захистити заплавні луки (оболоні).

Ялівець звичайний (Juniperus communis L.) автор порівнює зі світачем, тобто підсвічником для свічі біля ікони (Грінченко 4: 109). В образі ж самої свічки постає береза, яка росте поруч із ялівцем i вивершується над ним. Використовуючи образи підсвічника, названого старим українським словом «світач», та свічки («Світач» (Лазарук 100)), поет створює настрій храмової урочистості:

Наче світач, старий ялівець на горі.

В ньому свічка березова вгору

Догоряє й не може згоріть. (Лазарук 100)

Недарма на початку вірша поет порівняв сосновий ліс із кафедральним собором «Напівтемний собор кафедрального бору...».

У перекладі вірша білоруського поета-класика Максима Богдановича («3 Максима Богдановича» (Лазарук 103)) червоний колір листя осики й калини, якого набуває воно восени, Віктор Лазарук описав як кров i пожежу. Це надає рядкам ще тривожніших інтонацій порівняно 3 оригіналом, де згадані дерева не наливаються кров’ю, а «чырвоныя сыплюць лісты». В останніх рядках перекладу, як і в оригіналі Максима Богдановича, мохи поет характеризує епітетами, що надають відчуття затишку на болоті, альтернативного до тривоги та суму, притаманних узліссю.

У вірші «Осіння верстка» (Лазарук 104) ліс описано за допомогою оригінальних метафор та епітетів, які здебільшого мають «типографський» характер і надають пейзажу рис свіжонадрукованої газети:

На шпальтах осені -

Червона горобина і журавлина печаль.

Жирним корпусним шрифтом

Видрукувані в порожніх лісах дуби.

Тремтить церковна тінь ялинника

І замерзла роса. (Лазарук 104)

Фахова термінологія цих художніх засобів стосується набору та форматування тексту. Цілком імовірно, що специфіка вищезгаданих тропів пов'язана із професійною діяльністю Віктора Лазарука - він працював у 
редакції журналу «Жовтень», а згодом провідним редактором редакційновидавничого відділу Волинського державного університету імені Лесі Українки «Вежа». У контексті згадано і ялиновий ліс, тіні дерев якого автор порівнює із силуетами церков.

Реп'яхи поет асоціює з людськими гріхами, які так само чіпляються до людських душ, а лісові ягоди - із загадками, адже відшукати їх нелегко («Дідьків диптих») (Лазарук 107). Квітам латаття (Nymphaéa), які згадано у вірші під народною назвою «лілії», автор надає образу «ідилії білої» вочевидь, за колір і тендітність. Щоб розгледіти цю красу, поет пропонує «розсунути душею очерети», тобто захотіти побачити прекрасне, подолавши перепони.

За допомогою метафори поет змальовує дуби в образі гренадерів («Біла топографія» (Лазарук 111)). У європейських арміях XVII-XIX ст. так називали рід військ, до якого набирали високих та кремезних рекрутів. Сніг на розлогому гіллі - це еполети, тобто наплічні знаки розрізнення круглої форми 3 бахромою по колу, вони були й на гренадерських мундирах.

Елементами місцевого пейзажу, що дарував автору натхнення, $\epsilon$ такі дерева, як: ялина, береза, ялівець, осика, дуб («Нечімле. Intermecco» (Лазарук 122)). Деякі з них (березу, дуб) поет описує як вихідців із «Лісової пісні» Лесі Українки. Траву за допомогою метафори він перетворює на «зелений килим», а тишу порівнює за легкістю з пухом кульбаби.

У другій частині циклу «Нечімле» (Лазарук 126) згадано шум беріз, гриби та брусницю (Vaccinium vitis-idaea L.):

Я вам гукаю в красному бору,

Крізь шум березовий вас кличу.

Гриби й брусницю вдосвіта беру,

Вклоняюсь Дубу, і Вужеві, й Знічу... (Лазарук 126)

Ягоди брусниці часто використовують у народній медицині, зокрема варення з них - для лікування та профілкатики простудних захворювань, а також зміцнення імунної системи. Згадку про поширений на Поліссі ягідний промисел автор поєднує із давньою литовсько-руською традицією поклоніння хранителям лісу: Дубові, Вужеві та священному вогню - Знічу. Сакралізація предковічної природи Волині в творах Віктора Лазарука часто межує із похмурою хтонічністю, яка вабить таємницями потаємних місцин та їхніх духів-хранителів. У цьому вірші названо й низку інших рослин: горішина (ліщина), верес та ведмедина (ожина).

Вірш «Дуб дядька Лева» (Лазарук 126) вкотре декларує позицію автора - природа $\epsilon$ гарантом сивої давнини проти згубної та необачної господарської діяльності людей. Як у Лесиній «Лісовій пісні», всупереч заповітам дядька Лева, було зрубано задля матеріальної вигоди його дуб, так і в описаному поетом сьогоденні - знаходяться ті, хто готовий пустити під сокиру стародавні дерева задля плану з лісозаготівлі та власних потреб. Так, за словами поета, понищено дуби князів Курбського та 
Сангушка. Автор звертає увагу на те, що в новітні часи зникає старий бортницький промисел - відгомін сивої давнини, коли в поліських лісах поклонялися «язичницьким деревам-божествам». Нині все поросло братиками й травою, на заміну «велетням старим» посаджені молоді дерева. У вірші лунає заклик не рубати «живого древа» (тут недарма вжито старослов'янізм, адже до нащадків промовляє сама давнина) i не позбуватися власної самобутності та гідності.

Вечірню сутінь над рікою у вірші «Діалог» (Лазарук 128) автор називає «чорничною». У цьому ж вірші мавки, немов прості сільські господині, везуть на продаж полуниці з власного городу.

Захід сонця в поезії «Смеркання» (Лазарук 129) набуває червоного кольору, немов вимастившись за збиранням брусниці. Образу ялини на тлі заходу поет вкотре надає релігійного забарвлення, порівнюючи дерево із ченцем у монастирі, який «засвічує вечірню».

Персоніфіковані «мавчині» берези («Мавчині берези» (Лазарук 130)) поет наділяє епітетами, що акцентують на схожості дерев до закоханих дівчат - «місячні», «невинні», «причинні». Тишу автор знову порівнює 3 легким пухом кульбаби, витворивши епітет «кульбабна». Варто наголосити, що стать беріз поет визначає також і чоловічу, зазначаючи, що в народній етимології трапляються і береза, і «берез». Красу цих дерев поет підносить до образу храмів, порівнюючи їх шум із літургією, а вже в наступному рядку - з мелодією бального танцю - полонезу. Берези також символізують юність та прийдешність, адже мавчині гаї летять у майбуття саме в «березових веселих літачках».

Орляку звичайному (Pteridium aquilinum (L.) Kuhn) - рослині з групи папоротеподібних - поет недарма надає рис орла: «Б’є крилами широкими орляк» («Страх» (Лазарук 132)), адже на поперечному зрізі крізь нижню частину черешка її судинні пучки нагадують геральдичного орла із розпростертими крилами. Хоча у вірші, найімовірніше, йдеться не про це. 3 орлиними крилами поет порівнює перисті листки рослини. У вірші також трапляється власне поліська назва папороті - шипероха (Лазарук 131). В іншому вірші цього ж циклу оранжевий колір шиперохи (папороті), якого вона набуває восени, порівняно з іржею («Осінь» (Лазарук 143)).

За допомогою цікавих панкосмічних перевтілень автор описує перший вітерець, що зринає 3 осоки та кущів ялівцю, а також погойдування сосон. Персоніфіковані образи рослин та стихія утворюють гармонійний добросусідський світ зі своїм життям, помітним для ока небайдужих до краси природи рідного краю («Доріжина» (Лазарук 133)).

У вірші «Ніч» (Лазарук 138), сповненому історичних образів, ялину поет порівнює з рейтаром:

Ялина, мов рейтар, врубалася в пітьму... (Лазарук 138)

Так називалась озброєна рушницями та пістолетами європейська кіннота XVI-XVII ст., яка в рукопашному бою використовувала палаші 3 
довгим прямим лезом. Ймовірно, з цією холодною зброєю порівнює Віктор Лазарук ялинові гілки.

Мохи у вірші «Я прилечу» (Лазарук 147), на яких любить відпочивати лось, порівняно з ганчір'ям. Тут також згадується і кринична вода 3 калиновим листком на дні відра. Саме ці невеликі дерева часто ростуть поруч із криницями. 3 давніх часів калину й вербу садили, позначаючи витоки джерел, де мала згодом стояти криниця. У цій поезії $\epsilon$ також рядки, у яких вказано на лікарські властивості вересу та журавлини:

Там чай із вересу, варення з журавлини:

Од нервів і од тиску заваріть! (Лазарук 147)

Відомо, що такий напій - справді хороший засіб проти стресу та безсоння, а варення з журавлини нормалізує тиск та поліпшує загальний стан серцево-судинної системи.

Згаданий у контексті п'єси «Вугор у росі» (Лазарук 148) горох автор описує епітетом «росяний», оскільки існує прикмета, що у серпневі росяні ночі вугрі виповзають із рік на поля та городи, аби поласувати горохом. Сплетіння водоростей у воді породжує чудернацькі тіні, загадковість яких автор підкреслює епітетом «химерні» («Вугор у росі» (Лазарук 167)). Мінорні епітети доповнюють персоніфікований образ осики - втілення старості та сумної неминучості («Осичина» (Лазарук 202)). Молодий дубок скраю болота за допомогою персоніфікації набуває рис життєрадісного юнака та символізує невичерпний молодечий оптимізм («Ой чого ти, дубочку, чого ти...» (Лазарук 211)). Пейзаж соснового лісу доповнений метафорою, завдяки якій густо встелена мохом місцина описана як м'який килим («Запрошення на риболовлю» (Лазарук 214)). Жовтий місяць у хмарах автор порівнює із переспілою динею на баштані («Балада про трясовини» (Лазарук 217)). Барвінок у поезії «Могила» (Лазарук 219) символізує вічну пам'ять та вічне життя, оскільки в українській традиції ця рослина супроводжує не лише весільний обряд, але використовується також і для озеленення могил. Яблуня у вірші «Мати» (Лазарук 223) $є$ втіленням жінки-матері з нелегкою долею та складним життєвим шляхом від юності до похилого віку. Фіксуємо широке викоритання персоніфікації: яблуня (як і згадані в контексті груші) слухає, шепоче, радіє, турбується та непокоїться.

Висновки та перспективи дослідження. Поетичні твори відзначаються насиченістю фітономенами, які $\epsilon$ вагомими компонентами як номінативних, такі і образних одиниць художнього тексту. Флористичні назви виступають продуктивним засобом творення стилістичної експресії тексту й надають йому емоційно-налаштованої романтичної наснаженості мінорного або мажорного звучання. Основними способами і прийомами поетичного освоєння флоролексикону виступають образно-тропеїчні перевтілення та символізація. Джерелом яскравої образності мовної тканини поезій слугують загальнонародні традиції використання найменувань із світу флори з урахуванням первісних уявлень предків, а 
також включення фітоназв у поетичний обіг із проявом індивідуальної неповторності в рамках творчості поета.

Фактичний матеріал засвідчує продуктивність використання флоролексем у ролі стилістем та експресем широкого емоційно-оцінного плану. Образна природа флоролексем підпорядкована індивідуальноавторському осмисленню. Більшість таких флоронайменувань характеризуються позитивно-емоційною або мінорною забарвленістю.

У численних пейзажних замальовках флоролексеми органічно вплітаються в мовно-поетичну структуру тексту, створюючи виразний локально-національний колорит зображуваного, характеризуючи сезонні зміни у природі, символізуючи атрибути простору (зокрема береза, дуб, верба, калина, тополя, осика), уособлюючи зв'язок поколінь, звеличуючи славне минуле та вселяючи віру у світле майбутнє.

\section{Список використаної літератури}

Коломієць, Інна. Флоролексеми в українській поезії II половини XX століття: функціонально-стилістичний аспект. Автореф. дис. ... канд. філол. наук: 10.02.01. Київ, 2003.

Кузьміна, Ірина. «Голос отчого краю». XIV Міжнародна наукова інтернет-конференція Advanced Technologies of Science and Education. URL: http://intkonf.org/kuzmina-ivgolos-otchogo-krayu/.

Лазарук, Віктор. Літораль. Київ: Радянський письменник, 1990.

Олєйнікова, Олена. Садові декоративні рослини. Харків: Веста, 2010.

Омельковець, Руслана. «Фітономени як засіб увиразнення текстів Володимира Лиса». Лінгвостилістичні студї, вип. 7, 2017, с. 112-20.

Словарь української мови, за ред. Б. Д. Грінченка. В 4 т. Київ, 1907-1909.

Фармацевтична енциклопедія. Київ: МОРІОН, 2010.

\section{References}

Kolomiyets, Inna. Florolexemes in Ukrainian poetry of the late 20-th century: functional-stylistic aspect. PhD Thesis Abstract. Kyiv, 2003.

Kuzmina, Iryna. "Holos otchoho kraiu". XIV Mizhnarodna naukova internet-konferentsiia Advanced Technologies of Science and Education. intkonf.org/kuzmina-iv-golosotchogo-krayu/

Lazaruk, Viktor. Litoral. Kyiv: Radianskyi pysmennyk, 1990.

Olieinikova, Olena. Sadovi dekoratyvni roslyny. Kharkiv : Vesta, 2010.

Omelkovets, Ruslana. "Phytonomen as a Means of Enhancing Expressiveness in the Texts by Volodymyr Lys", Linguostylistic Studies, iss. 7, 2017, pp. 112-9.

Slovar ukrainskoi movy, edited by B. D. Hrinchenko. 4 vols. Kyiv, 1907-1909.

Farmatsevtychna entsyklopediia. Kyiv: MORION, 2010. 